\title{
Genetically modified human myoblasts with eNOS may improve regenerative ability of myogenic stem cells to infarcted heart
}

\author{
Agnieszka Janeczek ${ }^{1 *}$, Agnieszka Zimna ${ }^{1 *}$, Natalia Rozwadowska ${ }^{1}$, Monika Fraczek ${ }^{1}$, \\ Paulina Kucharzewska², Marek Ruciński ${ }^{3}$, Tomasz Mietkiewski ${ }^{3}$, Tomasz Kolanowski ${ }^{1}$, \\ Agnieszka Malcher ${ }^{1}$, Maciej Kurpisz ${ }^{1}$ \\ ${ }^{1}$ Institute of Human Genetics, Polish Academy of Sciences, Poznan, Poland \\ ${ }^{2}$ Department of Medical Biotechnology, Faculty of Biochemistry, Biophysics and Biotechnology, Jagiellonian University, Krakow, Poland \\ ${ }^{3}$ Orthopaedics Department, Voivodship Hospital, Poznan, Poland
}

*Both authors have contributed equally to the study.

\begin{abstract}
Background: Modern therapies of post infarcted heart failure are focused on perfusion improvement of the injured myocardium. This effect can be achieved by, among other means, implanting stem cells which could be genetically modified with factors inducing the formation of new blood vessels in the post infarction scar area. Combined stem cell and gene therapy seems to be a promising strategy to heal an impaired myocardium. The creation of new blood vessels can be indirectly stimulated via factors inducing vascular endothelial growth factor synthesis, for example endothelial nitric oxide synthase (eNOS). The product of this enzyme, nitric oxide, is a molecule that can influence numerous physiological activities; it can contribute to vasodilation, stimulation of endothelial cell growth, prevention of platelet aggregation and leukocyte adhesion to the endothelium.

Aim: To verify the pro-angiogenic and regenerative potential of human primary myoblasts and murine myoblast cell line C2C12 transiently transfected with eNOS gene.

Methods: Stem cells (either human or murine) were maintained in standard in vitro conditions. Next, both types of myoblasts were modified using electroporation and lipofection (human and murine cells), respectively. The efficacy of the transfection method was evaluated using flow cytometry. The concentration of eNOS protein was measured by ELISA immunoassay. The biological properties of modified cells were assessed using an MTT proliferation test and DAPI cell cycle analysis. To verify the influence of oxidative stress on myoblasts, cytometric tests using Annexin $\mathrm{V}$ and propidium iodide were applied. To check possible alterations in myogenic gene expression of stem cells transduced by genetic modification, the myogenic regulatory factors were evaluated by real-time PCR. The function of genetic modification was confirmed by a HUVEC capillary sprouting test using myoblasts supernatants.

Results: Electroporation turned out to be an efficient transfection method. High amounts of secreted protein were obtained (in the range $2,000 \mathrm{pg} / \mathrm{mL}$ ) in both cell types studied. Moreover, the functionality of gene overexpression product was confirmed in capillary development assay. Human myoblasts did not exhibit any changes in cell cycle; however, eNOS transfected murine myoblasts revealed a statistically significant reduction in cell cycle ratio compared to controls $(p<0.001)$. In the case of myogenic gene expression, a decrease in Myogenin level was only detected in the human transfected myoblast population $(p<0.05)$.

Conclusions: The results of our study may suggest that transplantation of myoblasts overexpressing eNOS could be promising for cell therapy in regenerating the post infarction heart.
\end{abstract}

Key words: angiogenesis, myoblasts, stem cells, eNOS, regenerative medicine

Kardiol Pol 2013; 71, 10: 1048-1058

\section{Address for correspondence:}

Maciej Kurpisz, MD, PhD, Institute of Human Genetics Polish Academy of Sciences, ul. Strzeszyńska 32, 60-479 Poznań, Poland, tel: +48 $616579202 / 212$,

fax: +48618233 235, e-mail: kurpimac@man.poznan.pl

Received: 26.10.2012 Accepted: 20.03.2013

Copyright (C) Polskie Towarzystwo Kardiologiczne 


\section{INTRODUCTION}

Cardiovascular diseases, including heart attacks, are currently one of the leading causes of morbidity and mortality. The World Health Organisation reported in 2008 that diseases of the cardiovascular system were the cause of 17.3 million deaths worldwide, of which 4.5 million were in Europe [1]. Myocardial infarction (MI) results in the loss of cardiac cells due to insufficient blood supply, elicited by a block of coronary arteries. Over time, the loss of myocardial cells results in the formation of a post infarction scar. In most cases, this process requires two months to be completed. These structural changes result in thinning of the ventricular wall and subsequent dilation of the ventricle, a process called ventricular remodelling. This phenomenon may progress and lead to cardiac failure [2]. Nowadays, heart failure (HF) therapy is based on surgical and complementary pharmacological treatments, but so far no one has been able to fully restore the function of the damaged myocardium.

In the future, stem cell therapy could be a simple and non-invasive approach to the treatment of HF. Skeletal muscle stem cells are usually responsible for skeletal muscle regeneration after its injury. They are localised outside the sarcolemma, within the basal lamina of the muscle fibre. In physiological conditions, they are quiescent mononucleated cells called satellite cells [3], but when activated by stress or muscle trauma, they undergo transition into a proliferative state. This results in cell proliferation and differentiation into myoblasts. Subsequent fusion of the myoblasts gives rise to polynucleated myotubes which finally form a functional muscle fibre [4]. Myogenesis involves the action of transcription factors that belong to the family of genes called myogenic regulatory factors (MRF). Overexpression of early myogenic factors, i.e. Myf5 and MyoD, is necessary to activate satellite cells and allow the formation of myoblasts. Myogenin and Myf6 (or MRF4) are required for further differentiation of myoblasts into myotubes, and muscle fibres. Also Mef2 (a MADS-box family member transcription factor) is involved in myogenesis as an early marker of the myogenic lineage $[5,6]$.

Myoblast transplantation has become a promising way to treat MI. Taking into account that cardiomyocytes are structurally similar to myocytes, myoblasts can be considered to be good candidates for HF therapy. Moreover, the transplantation of autologous myoblasts reduces the risk of their rejection and the unipotent character of those stem cells excludes the possibility of tumour formation. They are also relatively resistant to ischaemia compared to cardiomyocytes [7-9].

Combined gene and cell therapy is eagerly pursued in the treatment of cardiac disease. The possible goal of gene therapy is to regenerate the cardiac muscle and to improve blood circulation in the injured myocardium. Gene transfection coding for pro-angiogenic factors could directly or indirectly enhance vascularisation of the ischaemic region. This can lead to an increase in perfusion and function of the infarcted myocardium [10]. Overexpression of the introduced genes can also improve cell viability at the target site. Vascular endothelial growth factor (VEGF) is a direct pro-angiogenic factor [11]; however, the process of formation of new blood vessels can be also indirectly stimulated by factors enhancing the production of VEGF such as the product of endothelial nitric oxide synthase (eNOS). eNOS catalyses the conversion of L-arginine to L-citrulline, finally producing nitric oxide (NO). NO exerts multiple physiological functions. It contributes to vasodilation, stimulates endothelial cells, and prevents platelet aggregation and leukocyte adhesion to the endothelium [12-15]. Previous studies have shown that NO plays a crucial role in many VEGF-induced actions. Lack of NO production (by eNOS) significantly inhibits VEGF-induced mitogenic and angiogenic effects $[16,17]$.

To date, experiments using eNOS gene transfer to the progenitor endothelial cells (EPCs) have been carried out. An approach was made to establish if the EPCs with ability to synthesise $\mathrm{NO}$ are able to inhibit neointimal hyperplasia. The study showed that implantation of genetically modified stem cells led to reconstruction of the damaged endothelium and markedly inhibited the neointima proliferation. The therapeutic effect was enhanced in the case of stem cells modified with eNOS as opposed to native EPCs. Thus, it could be a potential therapeutic strategy to contain vasculoproliferative diseases [18]. Verification of the therapeutic effect of bone marrow mononucleated cells (BMMCs) modified with eNOS gene in the treatment of limb ischaemia has also been conducted. It was proved that the combination of BMMCs and eNOS can induce capillary formation, and therefore might restore perfusion in the ischaemic region [19]. As regards heart disease, the therapeutic potential of eNOS was tested using a porcine heart model. Retroviral transfer of this gene resulted in induction of neovascularisation and improvement of left ventricular function [20].

The principal aim of our study was to determine the effect of eNOS gene transfection on human and murine myoblasts cultured in vitro. We investigated the effect of eNOS gene overexpression on cell cycle and proliferation, its angiogenic and myogenic potential, and apoptosis/necrosis in induced oxidative stress conditions.

\section{METHODS \\ Cells studied}

The human myoblast cells were obtained from muscle biopsy during the reconstruction of an anterior cruciate ligament. Cells were maintained in the standard Dulbecco's modified Eagle medium supplemented with $4.5 \mathrm{~g} / \mathrm{L}$ of glucose, $20 \%$ fetal bovine serum (Lonza Group, Base, Switzerland), 1\% antibiotics-Pen/Strep/Amphotericin B (Lonza Group, Base, Switzerland), 1\% Ultraglutamine (L-Alanylo-L-Glutamina, Lonza Group, Base, Switzerland), and bFGF as previously described [2]. 
The murine myoblast $\mathrm{C} 2 \mathrm{C} 12$ cell line was purchased from the American Type Culture Collection (Manassas, VA, USA). Cells were cultured in standard Dulbecco's modified medium with $4.5 \mathrm{~g} / \mathrm{L}$ of glucose, $10 \%$ fetal bovine serum, antibiotics and $1 \%$ Ultraglutamine.

Human umbilical vein endothelial cells (HUVECs), were used to examine the pro-angiogenic properties of transfected cells. HUVECs were obtained from human umbilical cord veins (LONZA) and cultured in endothelial basal medium supplemented with $10 \%$ fetal calf serum, hydrocortisone $(1 \mu \mathrm{g} / \mathrm{mL})$, bovine brain extract $(3 \mu \mathrm{g} / \mathrm{mL})$, gentamycin $(50 \mu \mathrm{g} / \mathrm{mL})$, amphotericin B $(50 \mu \mathrm{g} / \mathrm{mL})$, and epidermal growth factor $(10 \mu \mathrm{g} / \mathrm{mL})$.

All types of the cultured cells were maintained in standard in vitro conditions: $5 \% \mathrm{CO}_{2}, 37^{\circ} \mathrm{C}, 95 \%$ humidity. Cell medium was regularly changed every two days. Cell passages were performed by treatment with $0.25 \%$ solution of trypsin-EDTA (Sigma, St. Louis, MO, USA) at the appropriate time indicated by microscopic observations (i.e. $70-80 \%$ monolayer confluency).

\section{Plasmids}

Plasmid pEGFP-C1 (Clontech, Mountain View, CA, USA), containing coding sequence for green fluorescence protein (eGFP) was used to investigate the transfection efficiency.

Plasmid DNA expressing endothelial nitric oxide synthase (pCiNeo_eNOS) was constructed in the Institute of Human Genetics, Polish Academy of Sciences, Poznan, Poland. cDNA sequence for eNOS (in vector pBluescript KS) was a gift obtained from Prof. Phillip A. Marsden from Department of Medicine, University of Toronto. eNOS cDNA sequence was cut out of the original vector using restriction enzymes $X b a l$ and Sall, and subsequently cloned in the pCiNeo mammalian expression vector.

\section{eNOS gene transfer}

Endothelial nitric oxide synthase gene was introduced to human myoblasts using electroporation. Transfection was optimised using different concentrations of plasmid DNA, and electrical pulse characteristics. The eventual most efficient electroporation protocol for human myoblasts was as following: $3 \times 10^{6}$ cells were suspended in final volume of $200 \mu \mathrm{L}$ of F10 medium and transfected with $5.2 \mathrm{pmol}$ of plasmids. The following conditions were applied: one pulse, wavetension $160 \mathrm{~V}$, time pulse $15 \mathrm{~ms}$, cuvetts with $2 \mathrm{~mm}$ gap. Transfection procedure was performed under standard in vitro culture conditions [21].

The murine myoblasts were transfected using a FuGene Transfection reagent (Roche, Mannheim, Germany). This method uses liposomes to transfer the gene of interest. After reaching $60 \%$ confluence, the $\mathrm{C} 2 \mathrm{C} 12$ cells were transfected using lipofection. The transfection efficacy each time achieved $30-40 \%$, and the cells mortality increased to $40 \% 48 \mathrm{~h}$ after transfection.

Twenty four hours after electroporation, the medium in transfected cells was replaced. Evaluation of transfec- tion efficiency was investigated $48 \mathrm{~h}$ after the start point of electroporation. To determine electroporation efficiency, we used myoblasts transfected with pEGFP-C1 plasmid. Assessment was performed using a fluorescent microscope (Zeiss Axiovert 200 microscope) where the green-fluorescent protein in live cells could be observed. Transfection efficiency was also evaluated by flow cytometry assay. Cells were stained with propidium iodide and then incubated for $5 \mathrm{~min}$ in the dark. Finally, the percentage of GFP positive and PI positive cells was measured by using a Cell Lab Quanta SC MPL flow cytometer (Beckman Coulter, Fullerton, CA, USA) (Figs. 1, 2).

\section{eNOS immunoassay}

To determine the level of human eNOS protein in transfected myoblasts, we performed the ELISA quantitative assay (R\&D Systems, Abingdon, UK). The experimental conditions were maintained according to the manufacturer's protocol.

\section{Cell proliferation}

To investigate the proliferation rate of investigated cell populations, the Cell Proliferation Kit-MTT (Roche, Mannheim, Germany) was applied. The main assumption of the test is cleavage of tetrazolium salt to purple formazan crystals by metabolically active cells. The test was verified using an ELISA reader.

\section{Cell cycle analysis}

By staining cells with DAPI we can investigate at which stage of the cell cycle were transfected cells. In our experiments, cell cycle was evaluated using Nuclear Isolation and Staining solution NIM DAPI (Beckman Coulter, Fullerton, USA). The rate of cell division was calculated according to the formula: $(\mathrm{S}+\mathrm{G} 2):(\mathrm{S}+\mathrm{G} 0 / \mathrm{G} 1+\mathrm{G} 2)$

\section{Apoptosis/necrosis detection}

The process of apoptosis was detected using Annexin V-FITC Kit assay (Beckman Coulter, Fullerton, CA, USA). Upon the early stage of apoptosis, the phosphatidyloserine becomes exposed at the cell surface. Annexin $V$ has high affinity to phosphatidyloserine which is located on the outer site of the cell membrane under apoptotic conditions. Conjugation of Annexin with fluorescein isothiocyanate (FITC) provides labelling of the apoptotic cells. The Annexin V test was performed according to the laboratory manual. The oxidative stress was induced by adding $500 \mu \mathrm{M}$ and $200 \mu \mathrm{M}$ of $\mathrm{H}_{2} \mathrm{O}_{2}$ to human and murine myoblasts respectively during $24 \mathrm{~h}$ incubation.

\section{Sprouting test (pro-angiogenic test, proliferation of HUVEC)}

To evaluate the pro-angiogenic properties of transfected myoblasts, conditioned media from in vitro cultured cells were harvested and transferred to HUVEC cells aggregates. The media from myoblasts were transferred $48 \mathrm{~h}$ after the start of electroporation. The assay was based on measuring the length 

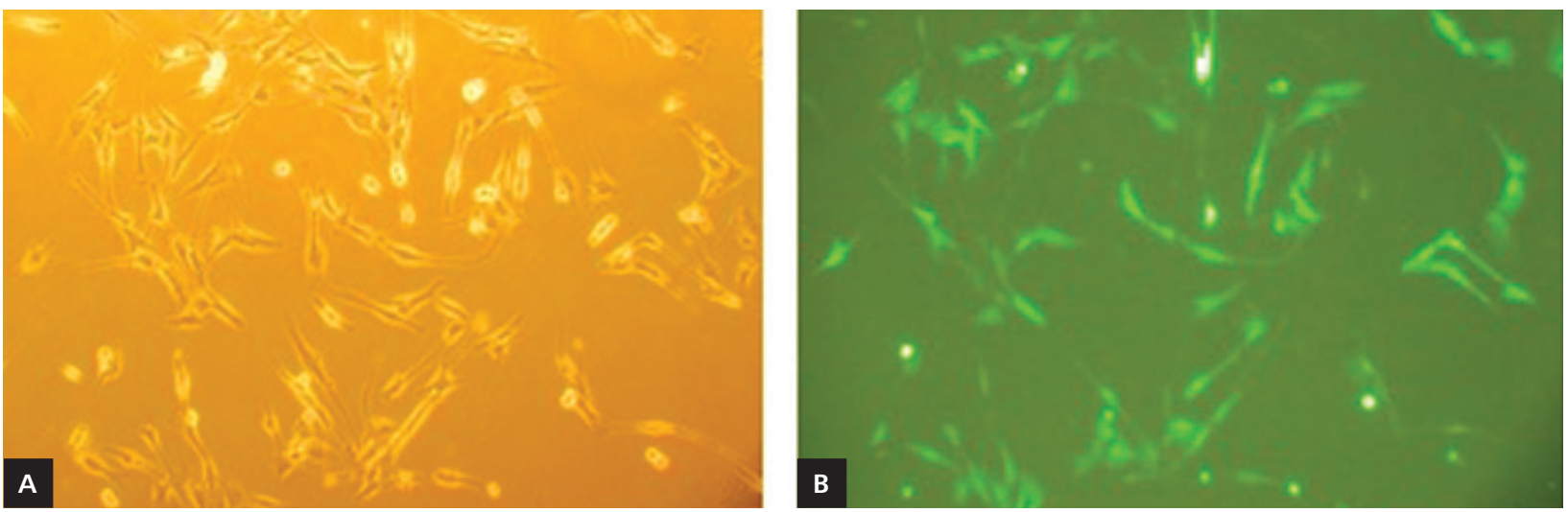

Figure 1. Optimisation of human myoblasts transfection. The maximum level of GFP-transfected cells, verified by flow cytometer Cell Lab Quanta ${ }^{\mathrm{TM}}$ SC MPL (Beckman Coulter, Fullerton, CA, USA) $48 \mathrm{~h}$ after the transfection procedure reached about 60\%. Pictures $\mathbf{A}$ and $\mathbf{B}$ correspond to the same human myoblast cell population seen under light and fluorescent microscopes, respectively
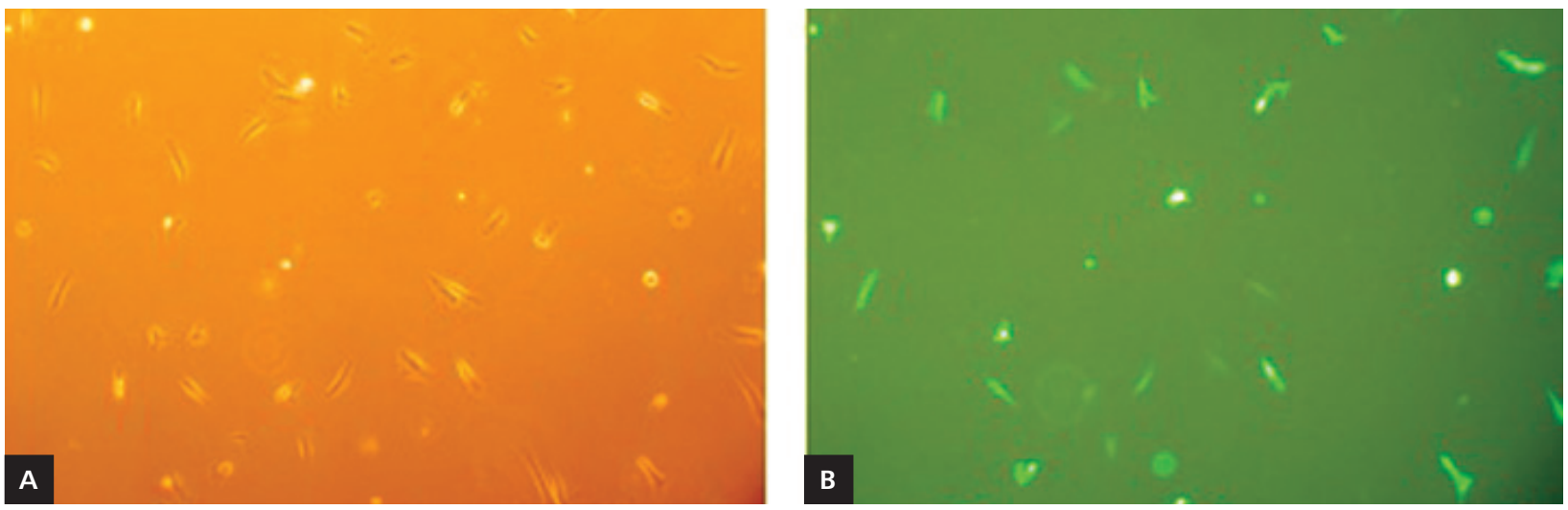

Figure 2. Optimisation of murine myoblasts transfection. Fluorescent microscope observation, $48 \mathrm{~h}$ after the transfection procedure. Pictures $\mathbf{A}$ and $\mathbf{B}$ correspond to the same C2C12 cell population sample

of capillaries sprouting from HUVEC cells aggregates. The test was performed according to the following conditions: HUVEC cells (approx. 700 cells) were incubated overnight in previously prepared methylcellulose in 96-well U-Shaped plates (Greiner, Freickenhausen, Germany). After overnight incubation, spheres were harvested and centrifuged. The HUVEC aggregates were gently mixed with solution containing $30 \%$ FBS and $1.2 \%$ methylcellulose. Meanwhile the collagen (obtained previously from rat tails) was neutralised using 0.2 M NaOH. After neutralisation, collagen was added to HUVEC cells resuspended in methylcellulose, then the cells were seeded on warm 24-well plates. Following 30 min incubation at $37^{\circ} \mathrm{C}$, the media from transfected myoblasts were transferred to spheroid cultures. Length assessment of formed capillaries was performed $48 \mathrm{~h}$ after media transfer.

\section{Real-time PCR}

In order to assess expression of myogenic genes, real-time polymerase chain reaction (PCR) was performed. Total RNA from transfected cells was extracted using Trizol Reagent
(Invitrogen, Carlsbad, CA, USA). To obtain pure mRNA fraction Oligo(dT)-dynabeads (Invitrogen, Carlsbad, CA, USA) were used. Subsequently, the cDNA was generated during reverse transcription reaction. Real-time PCR quantitative reaction was performed using an iCycler detecting system (Biorad, Hercules, CA, USA). The primers for specific genes were designed and purchased from Oligo Warsaw, Poland and have been listed in Table 1. Evaluation of gene expression was normalised using GAPDH and beta-actin as reference genes respectively for $\mathrm{C} 2 \mathrm{C} 12$ cells, and human myoblast cells. Each time, the specificity of the product was determined using melting curves and agarose gel electrophoresis.

\section{Statistical analysis}

Each experiment was performed at least twice and each experimental group was repeated in triplicate. Data was analysed using ANOVA test with correction of Tukey for unrelated variables, Kruskal-Wallis test (with correction of Dunn's for multiple groups comparison) and $\chi^{2}$ test were applied. Data was presented as means \pm standard deviation 
Table 1. Primer sequences used in real-time PCR reactions

\begin{tabular}{|c|c|c|c|}
\hline Gene name & Primer name & Primer sequence & Product size \\
\hline \multirow{3}{*}{ mGAPDH } & GAPDH_f & 5'-GGAGAAACCTGCCAAGTAT-3' & \\
\hline & GAPDH_r & 5'-AGCCGTATTCATTGTCATA-3' & $221 \mathrm{bp}$ \\
\hline & $A_{c t B} f$ & 5'-GGCTGTATTCCCCTCCATC-3' & \\
\hline \multirow[t]{2}{*}{ mActB } & ActB_r & 5'-CCAGTTGGTAACAATGCCAT-3' & $190 \mathrm{bp}$ \\
\hline & MYOG_f & 5'-CAGTACATTGAGCGCCTACAG-3' & \\
\hline \multirow[t]{2}{*}{ mMYOG } & MYOG_r & 5'-GGACCGAACTCCAGTGCAT-3' & $164 \mathrm{bp}$ \\
\hline & Myf5_f & 5'-CCTGTCTGGTCCCGAAAGAAC-3' & \\
\hline \multirow[t]{2}{*}{ mMyf5 } & Myf5_r & 5'-GACGTGATCCGATCCACAATG-3' & $131 \mathrm{bp}$ \\
\hline & Myf6_f & 5'-ATCAGCTACATTGAGCGTCTACA-3' & \\
\hline \multirow[t]{2}{*}{ mMyf6 } & Myf6_r & 5'-CCTGGAATGATCCGAAACACTTG-3' & $176 \mathrm{bp}$ \\
\hline & MyoD_f & 5'-GCTGCCTTCTACGCACCTG-3' & \\
\hline \multirow[t]{2}{*}{ mMyoD } & MyoD_r & 5'-GCCGCTGTAATCCATCATGC-3' & $120 \mathrm{bp}$ \\
\hline & Mef2_f & 5'-CAGGCGCTATGGGTCATCTG-3' & \\
\hline \multirow[t]{2}{*}{ mMef2 } & Mef2_r & 5'-GCTACTTGGATTGCTGAACTGC-3' & $100 \mathrm{bp}$ \\
\hline & ActB $_{-} f$ & 5'-GCTGTATGAGACATCCCCCTA-3' & \\
\hline \multirow[t]{2}{*}{ hActB } & ActB_r $r$ & 5'-ATCTTGATCTTCATTGTGCTG-3' & $192 \mathrm{bp}$ \\
\hline & eNOS_f & 5'-CAGCATCCCTACTCCCACCAGC-3' & \\
\hline \multirow[t]{2}{*}{ heNOS } & eNOS_r & 5'-GAGCCCAGGCAGCGTCTTG-3' & $181 \mathrm{bp}$ \\
\hline & MYOG_f & 5'-GCTGTATGAGACATCCCCCTA-3' & \\
\hline \multirow[t]{2}{*}{ hMYOG } & MYOG_r & 5'-CGACTTCCTCTTACACACCTTAC-3' & $226 \mathrm{bp}$ \\
\hline & Myf5_f & 5'-TGCAGGAGTTGCTGAGAGAGCA-3' & \\
\hline \multirow[t]{2}{*}{ hMyf5 } & Myf5_r & 5'-CAGGACTGTTACATTCGG-3' & $120 \mathrm{bp}$ \\
\hline & Myf6_f & 5'-CTTCAGCTACAGACCCAAACA-3' & \\
\hline \multirow[t]{2}{*}{ hMyf6 } & Myf6_r & 5'-CCTGGAATGATCGGAAACAC-3' & $94 \mathrm{bp}$ \\
\hline & Myod_f & 5'-ACGGCATGATGGACTACAG-3' & \\
\hline \multirow[t]{2}{*}{ hMyoD } & MyoD_r & 5'-CGACTCAGAAGGCACGTC-3' & $212 \mathrm{bp}$ \\
\hline & Mef2_f & 5'-AGATACCCACAACACACGCG-3' & \\
\hline hMef2 & Mef2_r & 5'-ATCCTTCAGAAAGTCGCATGC-3' & 193 bp \\
\hline
\end{tabular}

GAPDH — glyceraldehyde-3-phosphate dehydrogenase; Myf5 - myogenic factor 5; MyoD - myogenic differentiation 1; MYOG — myogenin; MRF4(Myf6) - myogenic factor 6; Mef2 - myocyte enhancer factor 2; eNOS - endothelial nitric oxide; ActB - beta-actin

or as medians \pm average deviation (in the case of myogenic genes expression).

\section{RESULTS}

C2C12 and human myoblast transfection efficiency We optimised the concentration of plasmid DNA prior to gene transfer. Two days after electroporation, we evaluated the transfection efficiency using flow cytometry. In both cell types, the amount of genetically modified cells reached $80-90 \%$. This method was highly efficient, but we must take into account that after electroporation the mortality of cells may reach $40-50 \%$. Human myoblast cells as well as $\mathrm{C} 2 \mathrm{C} 12$ murine myoblast cells transfected with pCiNeo-eNOS plasmid using FuGene
Table 2. Concentrations of eNOS protein obtained in human and murine myoblast cells

\begin{tabular}{|llc|}
\hline Transfected cell populations & eNOS [pg/mL] \\
\hline Murine myoblasts & eNOS & $2,012 \pm 100$ \\
& Control & 0 \\
Human myoblasts & eNOS & $2,189 \pm 579$ \\
& Control & $15 \pm 6$ \\
\hline
\end{tabular}

HD Transfection Reagent (Roche, Mannheim, Germany) exhibited high expression of eNOS protein. Concentrations of these proteins secreted to supernatant are shown in Table 2. 

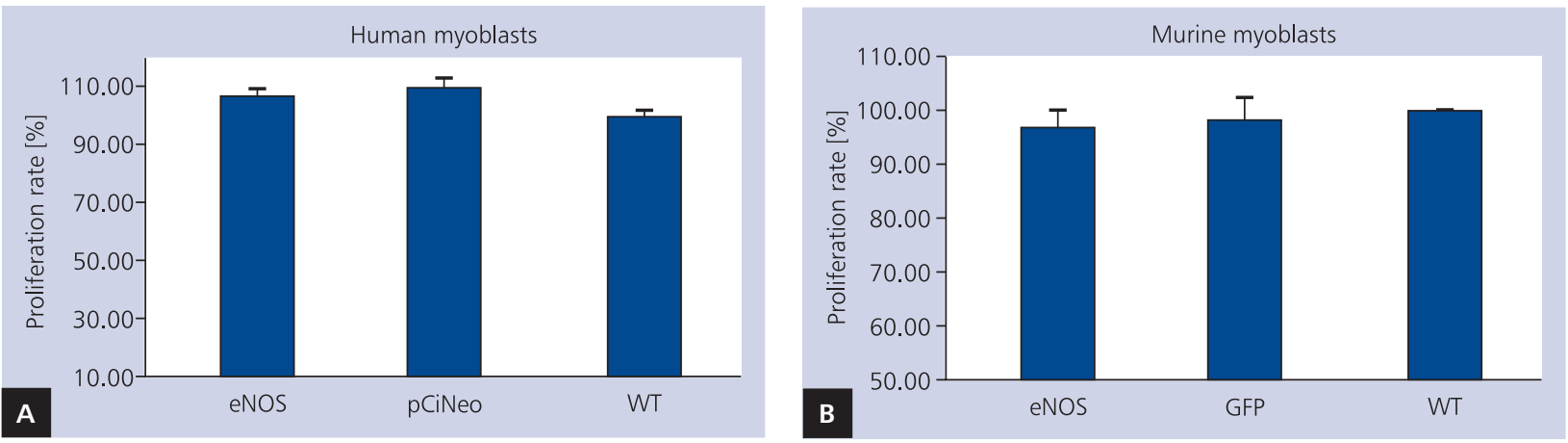

Figure 3. Cell proliferation evaluated by MTT test; A. Human myoblast: eNOS - cell transfected with eNOS ORF;

pCiNeo - mock-transfected cells; WT — wild type myoblasts; B. Murine myoblasts: eNOS — transfected murine myoblast cells; GFP — GFP transfected murine myoblasts; WT — wild type mouse myoblasts. No statistically significant differences were found among cell populations of both studied cell types
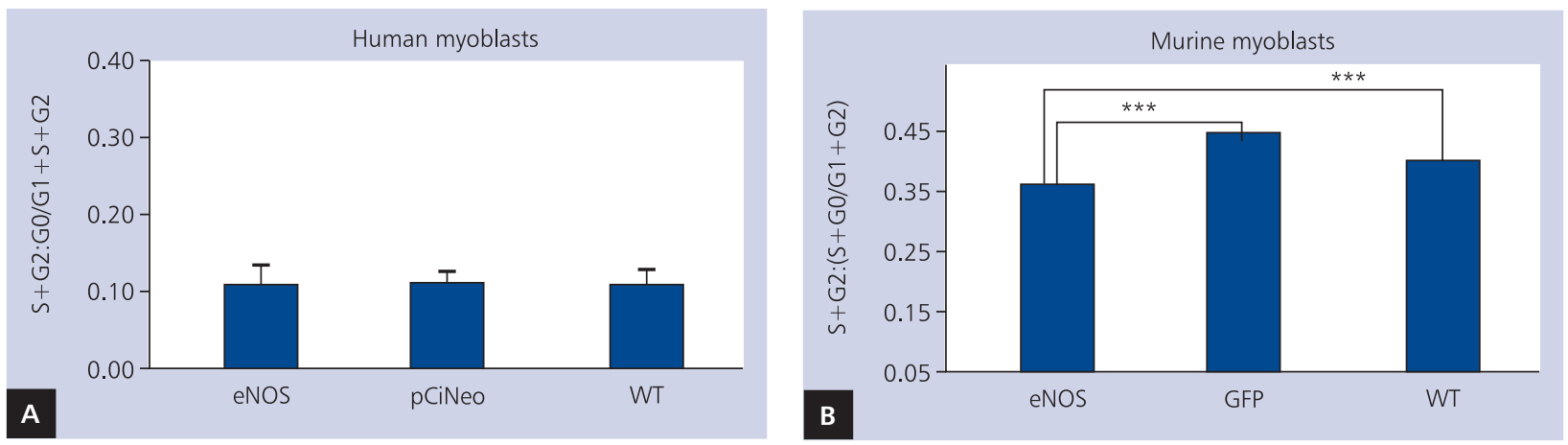

Figure 4. Cell cycle analysed by NIM-DAPI staining. Minimum $10^{6}$ cells were analysed in both cases. The proliferation ratio was calculated from: $(\mathrm{S}+\mathrm{G} 2)$ :(S+GO/G1+G2). A. Human myoblast: eNOS - cell transfected with eNOS ORF; pCiNeo - mocktransfected cells; WT — wild type myoblasts. There was no statistical significance between cell populations under study. B. Murine myoblasts: eNOS — transfected murine myoblast cells; GFP — GFP transfected murine myoblasts; WT — wild type mouse myoblasts. The statistical significance $\left.p<0.001^{* * *}\right)$ was revealed

\section{Proliferation of the transfected cells}

There were no significant differences between wild type and genetically modified cells (eNOS or mock-transfected cells). In the case of such a severe intervention as electroporation or lipofection, it seems that myoblasts are rather stable cells and quite resistant to stressful conditions (Fig. 3).

\section{Cell cycle analysis}

Cell cycle analysis revealed that the proliferation rate $(\mathrm{S}+\mathrm{G} 2):(\mathrm{S}+\mathrm{G} 0 / \mathrm{G} 1+\mathrm{G} 2)$ of the $\mathrm{C} 2 \mathrm{C} 12$ genetically modified myoblasts was generally higher than transfected human myoblasts (Fig. 4). Murine eNOS transfected cells exhibited significantly higher proliferation than wild type cells, however this has not been the case with human myoblasts.

\section{Sprouting test (pro-angiogenic test, proliferation of HUVEC)}

Proliferation of HUVEC cells confirmed the pro-angiogenic potential of eNOS gene. Conditioned media collected from eNOS (gene) transfected myoblasts significantly improved proliferation of HUVEC cells, and increased the capillary formation compared to the amount of HUVEC capillaries cultured in standard medium (Fig. 5).

\section{Myogenic gene expression}

In the case of $\mathrm{C} 2 \mathrm{C} 12$ genetically modified cells, we did not observe a statistically significant effect in the expression of myogenic genes. Generally, the murine myoblast cell line exhibited low expression of Myogenin, MyoD, and MRF4, while the expression of Myf5 and Mef2 remained high. In human genetically modified myoblasts (after electroporation), Myogenin was significantly decreased. In this cell population we also observed a high level of Myf5 transcription, but it did not reach the statistical significance (Fig. 6).

\section{Apoptotic/necrotic cells detection in in vitro oxidative stress conditions}

We investigated the apoptosis/necrosis in human myoblasts and $\mathrm{C} 2 \mathrm{C} 12$ murine cells subjected to conditions of oxidative 


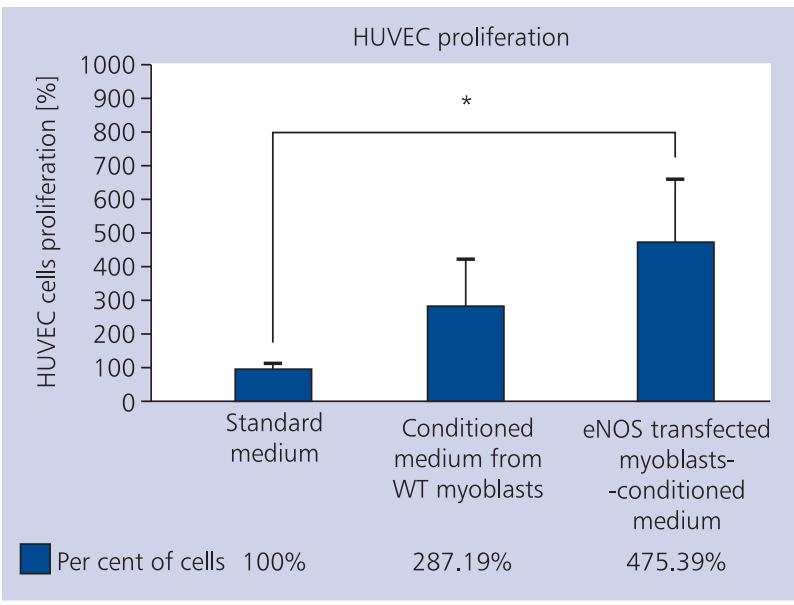

Figure 5. Angiogenic assay - proliferation of HUVEC cells. Statistical significance $p<0.05\left(^{*}\right)$ between samples with standard medium and eNOS-conditioned medium has been calculated out of two independent cell samples that were repeated thrice; WT — wild type

stress. To murine myoblasts $200 \mu \mathrm{M}$ of hydrogen peroxide was added, but human cells did not respond to such $\mathrm{H}_{2} \mathrm{O}_{2}$ concentration. We then adopted an optimisation procedure with a range of $\mathrm{H}_{2} \mathrm{O}_{2}$ concentrations in which human 'native' myoblasts significantly responded to exerted oxidative stress by apoptosis. Our experiments indicated the most efficient dose of hydrogen peroxide for $500 \mu \mathrm{M}$.

After $24 \mathrm{~h}$ of oxidative stress conditions, we noted that all the cell types under study exhibited an increase in the number of apoptotic and necrotic cells and reduced their viability, whereas the unstressed cell samples generally presented high amounts of live cells with low numbers of apoptotic or necrotic cells. The viability of eNOS transfected cells in human myoblast cell population did not much differ from wild type cells maintained under oxidative stress conditions (Fig. 7A). However, in the case of murine C2C12 myoblasts (Fig. 7B), the introduction of eNOS gene significantly increased a percentage of viable cells after stress conditions compared to wild type cells, but this was not the case with human eNOS-transfected cells.

\section{DISCUSSION}

In the present study we evaluated the effect of eNOS gene transfection on murine and human myoblasts. After introducing the investigated gene to the cells, we assessed the influence of the transfection process on basic cell biology (i.e. proliferation and cell cycle). Subsequently, we evaluated the expression of implemented eNOS transgene (at the mRNA and protein level).

Transfection efficacy, overexpression of eNOS gene The gene was introduced to human myoblasts using an electroporation system. To achieve sufficient efficacy, we managed to optimise the transfection procedure using various concentrations of plasmid and electroporation conditions. In spite of high cell mortality (about 40-50\%), the percentage of human cells with incorporated transgene increased compared to other methods applied such as lipofection. Similar results were achieved in previous studies which showed that electroporation can yield a high efficacy of gene transfer into proliferating human myoblasts, preserving its ability to self-renewal [21]. C2C12 murine cells are easier to be maintained and genetically modified, while human myoblasts have been proved to be more difficult at applied genetic engineering. In our previous studies, we used lipofection to overexpress a gene of interest to both types of cells. While the amount of transfected C2C12 cells was acceptable, the primary human myoblasts exhibited poor transfection efficiency. We next tried to optimise lipofection conditions protocol and agents for human myoblasts; none of them gave a satisfactory result. Therefore we finally used the electroporation protocol for human primary cell suspensions.

We received also a high expression of functional protein. Taking into account the high expression of derived functional protein, we may speculate that engraftment of myoblasts modified with eNOS gene to post ischaemic heart tissue may lead to the initiation of a cascade of blood vessel formation.

\section{Proliferation and cell cycle of the transfected cells}

Recent studies have shown that eNOS gene overexpression in endothelial cells enhanced their proliferation as well as their migration. In the ischaemic area of transfected pig hearts, expression of eNOS was found to be higher than in nonischaemic region [22]. In addition, in vitro eNOS transfection of endothelial cells was sufficient to induce increased proliferation of hypoxic coronary endothelial cells. In the case of vascular smooth muscle cells, the eNOS gene transfer caused cessation of proliferation, which also had a good influence on angiogenesis. Overexpression of the eNOS gene in human and murine myoblasts did not affect their rate of in vitro proliferation. Lack of influence of eNOS transfection on the cell proliferation rate might indicate that in infarcted myocardium, myoblasts should rather enhance a proliferation and migration of local endothelial cells.

Murine and human myoblasts exhibited little difference in cell cycle analysis. The C2C12 murine cells showed a higher rate of cell division than human myoblasts. Differences in cell division rate between these two types of stem cells may result from various cells characteristics. Murine myoblasts reach a high confluence faster than human cells, and after transfection $\mathrm{C} 2 \mathrm{C} 12$ cells need less time to regenerate themselves.

\section{Sprouting test (pro-angiogenic test, proliferation of HUVEC)}

Conditioned media from eNOS transfected myoblasts significantly increased the amounts and length of capillary formation 


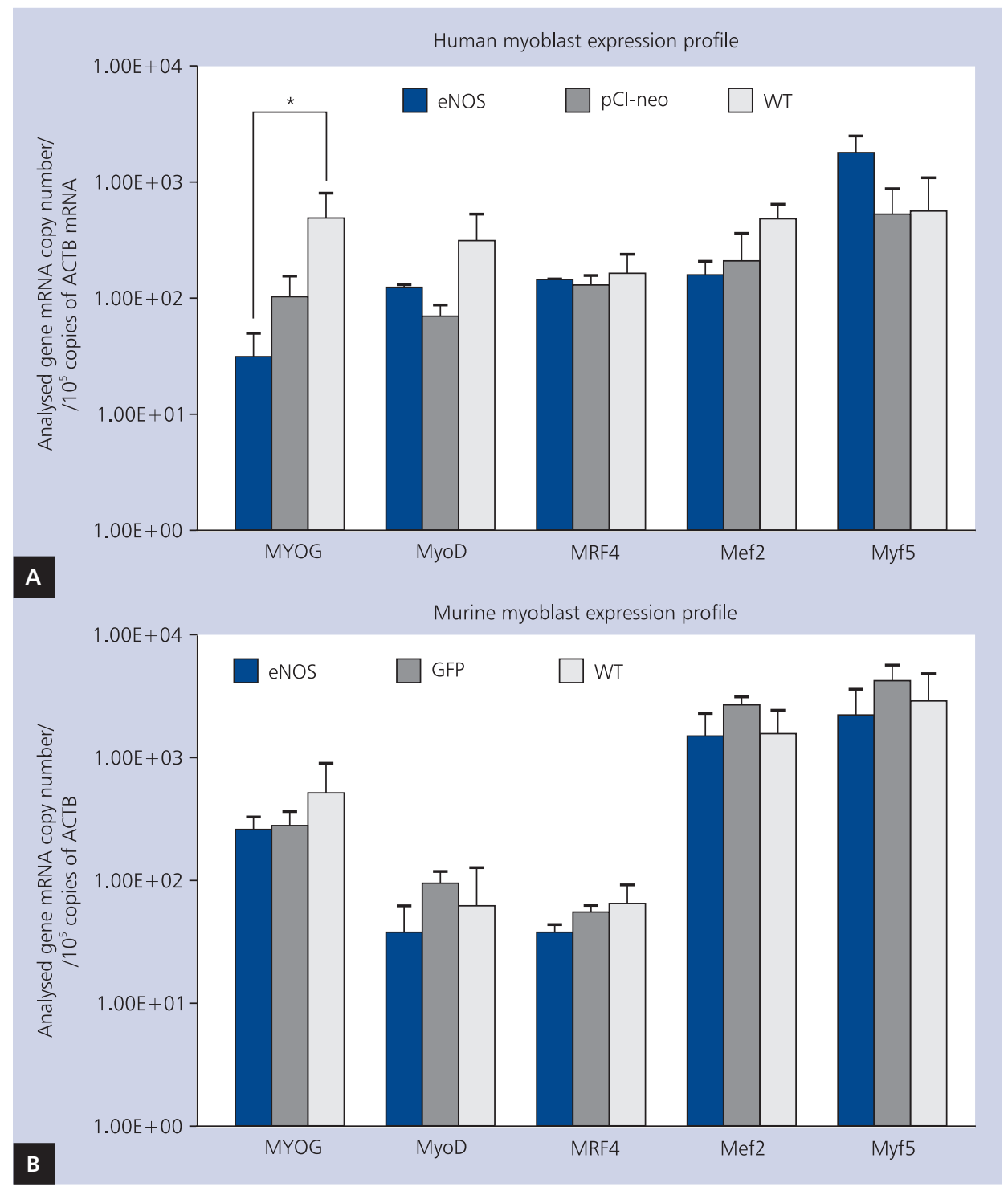

Figure 6. Myogenic gene expression: A. Human myoblast cells, $n=5$ experiments. B. Murine myoblast cells, no statistical significance between studied cell populations was revealed, with the exception of myogenin profile — statistical significance $p<0.05\left(^{*}\right)$ between eNOS tranfected myoblasts and wild type cells; MYOG - myogenin; MyoD - myogenic differentiation 1; MRF4(Myf6) - myogenic factor 6; Mef2 - myocyte enhancer factor 2; Myf5 - myogenic factor 5; eNOS — cell transfected with eNOS ORF; pCi-Neo — mock-transfected cells; GFP — GFP transfected murine myoblasts; WT — wild type myoblasts

(Fig. 5) compared to control standard medium. This may indicate good pro-angiogenic properties of eNOS. We can assume that the increase of capillaries formation may provide an improvement in oxygenation and nutrient supply in local myocardial environment.

\section{Myogenic gene expression analysis}

Murine myoblast transfection of eNOS did not exert a statistically significant effect on the myogenic genes expression profile. C2C12 cells in general exhibited high levels of Myf5 and Mef2 transcription factors. Myogenic gene investigation in human myoblast cells told us that only the Myogenin level had significantly decreased after electroporation. The expression of Myogenin increases in the final stage of myogenesis, and it is characteristic to the cells already differentiated into myotubes. Therefore, a decrease in Myogenin expression may lead to the extension of proliferation time and can slow down the process of muscle fibre formation [6]. Relatively high expression of Myf5 transcription factor observed in both cell types (particularly visible in the case of eNOS transfected human myoblasts) may suggest a high proliferative potential for studied myoblasts. The Myf5 gene and the MyoD gene are involved in the early stages of myogenesis [23]. We can assume that transfected myoblasts will be able therefore to fill 


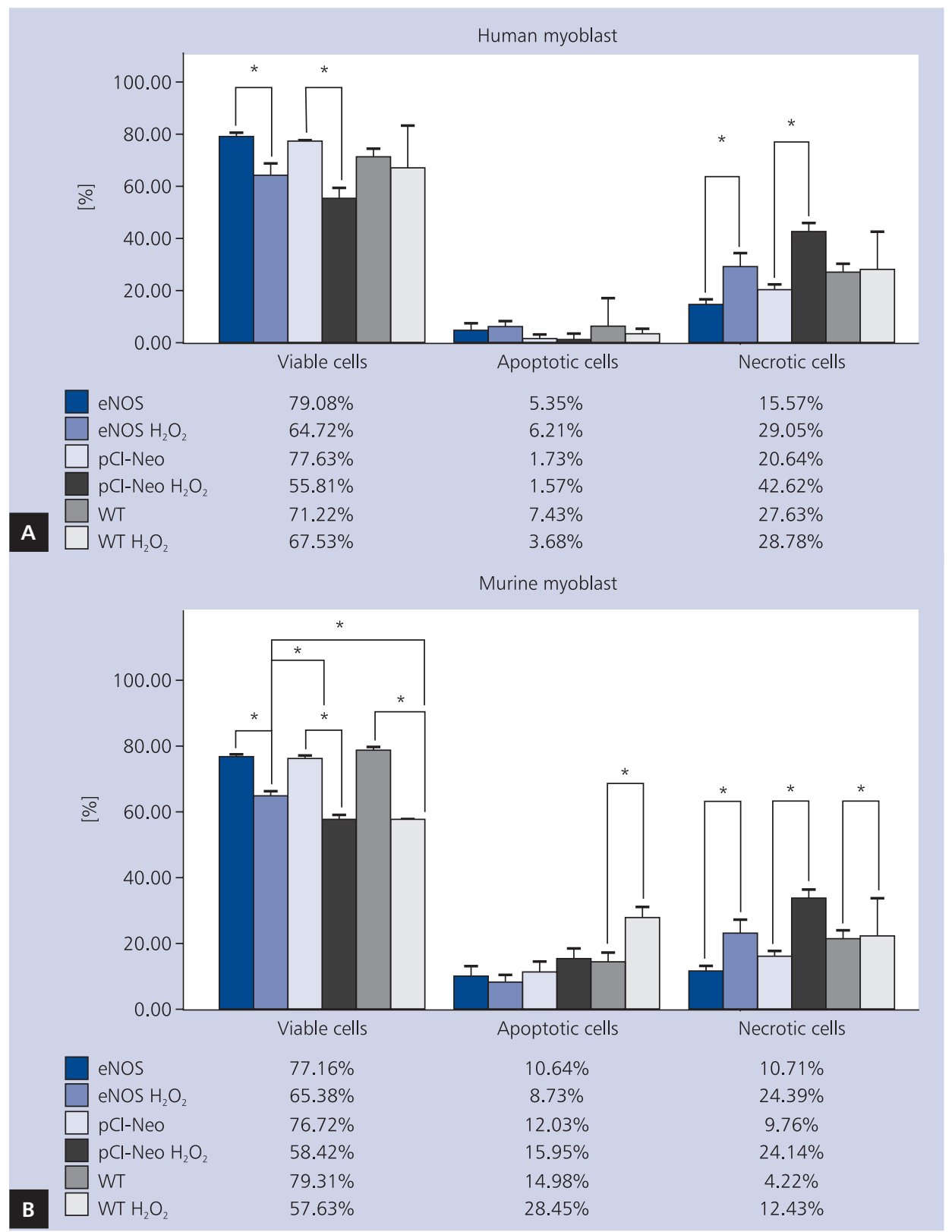

Figure 7. The percentages of viable, apoptotic and necrotic cells (evaluated by flow cytometry). A. Human myoblasts with or without $\mathrm{H}_{2} \mathrm{O}_{2}$ incubation; statistical importance $\mathrm{p}<0.05\left(^{*}\right)$; eNOS - cell transfected with eNOS ORF; pCi-Neo — mock-transfected cells; WT - wild type myoblasts. B. Murine myoblasts with or without $\mathrm{H}_{2} \mathrm{O}_{2}$ incubation; statistical importance $\mathrm{p}<0.05\left(^{*}\right)$; eNOS — transfected murine myoblast cells; GFP — GFP transfected murine myoblasts; WT — wild type murine myoblasts

the scar area in a post infarction heart and such engraftment could be effective. Due to the low Myogenin expression, the time for final cell differentiation will be extended - and cells will have sufficient time to proliferate, thereby producing a pro-angiogenic factor.

\section{Apoptotic/necrotic cells detection in oxidative stress conditions}

After $\mathrm{Ml}$ in the scar area, there exists a hypoxic environment [24]. Therefore cells which are being considered to be implanted to a post infarction heart must be able to survive in hypoxic conditions. Oxidative stress is the integral part of the inflammatory response after MI [25]. We investigated the influence of oxidative stress on human and murine myoblast cells using $200 \mu \mathrm{M}$ and $500 \mu \mathrm{M}$ concentrations of hydrogen peroxide exerted to murine and human myoblasts, respectively. Different concentrations of $\mathrm{H}_{2} \mathrm{O}_{2}$ applied to investigated cell types was caused by a lack of vulnerability of human myoblasts to oxidative stress exerted by $200 \mu \mathrm{M}$ solution. We then performed an optimisation of stress conditions separately 
to each stem cell type establishing more adequate conditions to human myoblasts at $500 \mu \mathrm{M} \mathrm{H}_{2} \mathrm{O}_{2}$ concentration. From the experiments performed (Fig. 7), we can assume that myoblasts overexpressing eNOS gene may have a sufficient ability in order to survive in a hostile environment (in infarcted hearts), and therefore can be applied as a therapeutic tool in regenerative medicine. Such a conclusion has been exemplified by non-significant differences between genetic modified human myoblast viability in oxidative stress conditions versus 'native' cells (Fig. 7A); however, this has to be verified in further functional assays set up in a pre-clinical scenario.

Both cell types under study exhibited similar high viability after $24 \mathrm{~h}$ of incubation in stress conditions, although the C2C12 cells after eNOS gene transfer maintained in medium with hydrogen peroxide showed statistically significant higher viability compared to myoblasts modified with GFP, and wild ('native') cells. In human myoblast cells transfected with eNOS gene, the resistance to oxidative stress was similar to the other studied human cell populations maintained in a similar amount of hydrogen peroxide (Fig. 7A). Taking into account that in post infarcted myocardium cells often undergo apoptosis, we can assume that genetically modified myoblasts with eNOS gene may perform its role also in in situ conditions [25].

\section{CONCLUSIONS}

Based on the results of all performed tests, we suggest that engraftment of myoblasts overexpressing eNOS gene may potentially lead to an improvement of post infarcted heart condition. Investigated (transfected) cells preserved their ability to proliferation, and differentiation, subsequently exhibiting the high amount of nitric oxide produced by high concentration of eNOS protein. Rewarding viability of investigated cells under oxidative stress conditions may indicate that their engraftment will be suitable for the ischaemic condition prevailing in an infarcted heart. All these in vitro studies may therefore lead to the beginning of pre-clinical studies.

\section{Acknowledgements}

This study was supported by grants from the Ministry of Science (NCBiR), No R13 006506 and Polpharma Scientific Foundation III/11/2004.

\section{Conflict of interest: none declared}

\section{References}

1. World Health Organisation, Cardiovascular Diseases, Statistics on chronic diseases and risk factors http://www.who.int/topics/cardiovascular_diseases/en/index.html.

2. Laflamme M, Murry CE. Regenerating the heart. Nat Biotech, 2005; 7: 845-856.

3. Seidel M, Rozwadowska N, Tomczak K, Kurpisz M. Myoblast preparation for transplantation into injured myocardium. Eur Heart J, 2006; Suppl. H: H8-H15.

4. Menasche P. Skeletal myoblasts and cardiac repair. J Mol Cell Cardiol, 2008; 45: 545-553.

5. Megeney LA, Rudnicki MA. Determination versus differentiation and the MyoD family of transcription factors. Biochem Cell Biol,
1995; 73: 723-732.

6. Pownall ME, Gustafsson MK, Emerson ChP. Myogenic regulatory factors and the specification of muscle progenitors in vertebrate embryos. Annu Rev Cell Dev Biol, 2002; 18: 747-783.

7. Potthoff MJ, Wu H, Arnold MA et al. Olson1 Histone deacetylase degradation and MEF2 activation promote the formation of slow-twitch myofibers. J Clin Invest, 2007; 117: 2459-2467.

8. Siminiak T, Kalawski R, Fiszer D et al. Autologous skeletal myoblast transplantation for the treatment of postinfarction myocardial injury: phase I clinial study with 12 months follow-up. Am Heart J, 2004; 148: 531-537.

9. Horackova M, Arora R, Chen R et al. Cell transplantation for treatment of acute myocardial infarction: unique capacity for repair by skeletal muscle satellite cells. Am J Physiol Heart Circ Physiol, 2004; 287: H1599-H1608.

10. Khan TA, Selke FW, Laham RJ. Gene therapy progress and prospects: therapeutic angiogenesis for limb and myocardial ischemia. Gene Therapy, 2003; 10: 285-291.

11. Maulik N, Thirunavukkarasu M. Growth factor/s and cell therapy in myocardial regeneration. J Mol Cell Cardiol, 2008; 44: 219-227.

12. Becker C, Lacchini S, Muotri AR et al. Skeletal muscle cells expressing VEGF induce capillary formation and reduce cardiac injury in rats. Int J of Cardiol, 2006; 113: 348-354.

13. Ziche M, Morbidelli L, Masini E et al. Nitric oxide mediates angiogenesis in vivo and endothelial cell growth and migration in vitro promoted by substance PJ Clin Invest, 1994; 94: 2036-2044.

14. Dimmeler S, Hermann C, Galle J et al. Upregulation of superoxide dismutase and nitric oxide synthase mediates the apoptosis-suppressive effects of shear stress on endothelial cells. Arterioscler Thromb Vasc Biol, 1999; 19: 656-664.

15. Ziche M, Parenti A, Ledda F et al. Nitric oxide promotes proliferation and plasminogen activator production by coronary venular endothelium through endogenous bFGF. Circ Res, 1997; 80: 845-852.

16. Jozkowicz A, Cooke JP, Guevarab I et al. Genetic augmentation of nitric oxide synthase increases the vascular generation of VEGF. Cardiovasc Res, 2001; 51: 773-783.

17. Hood JD, Meininger CJ, Ziche M, Granger HJ. VEGF upregulates ecNOS message, protein, and NO production in human endothelial cells. Am J Physiol, 1998; 274: H1054-H1058.

18. Kong D, Melo LG, Mangi AA et al. Enhanced inhibition of neointimal hyperplasia by genetically engineered endothelial progenitor cells. Circulation, 2004; 109: 1769-1775.

19. Mees B, Récalde A, Loinard C et al. Endothelial nitric oxide synthase overexpression restores the efficiency of bone marrow mononuclear cell-based therapy. Am J Pathol, 2011; 178: 55-60.

20. Kupatt C, Hinkel R, von Brühl ML et al. Endothelial nitric oxide synthase overexpression provides a functionally relevant angiogenic switch in hibernating pig myocardium. J Am Coll Cardiol, 2007; 49: 1575-1584.

21. Espinos E, Liu JH, Bader CR, Bernheim L. Efficient non-virial DANN mediated gene transfer to human primary myoblasts using electroporation. Neuromusular Disorders, 2001; 11: 341-349.

22. Cui B, Huang L, Fang Y et al. Transplantation of endothelial progenitor cells overexpressing endothelial nitric oxide synthase enhances inhibition of neointimal hyperplasia and restores endothelium-dependent vasodilatation. Microvascular Res, 2001; 81: 143-150.

23. Seale P, Rudnicki MA. A new look at the origin, function, and stem-cell status of muscle satellite cells. Developmental Biol, 2000; 218: 115-124.

24. Menasche P. Cardiac cell therapy: lessons from clinical trials. J Mol Cell Cardiol, 2011; 50: 258-265.

25. Kaminski KA, Bonda TA, Korecki J, Musial WJ. Oxidative stress and neutrophil activation the two keystones of ischemia/reperfusion injury. Int J Cardiol, 2002; 86: 41-59. 


\title{
Poprawa właściwości regeneracyjnych komórek macierzystych pochodzenia miogennego poprzez zastosowanie modyfikowanych genetycznie mioblastów w terapii serca po zawale
}

\author{
Agnieszka Janeczek ${ }^{1 *}$, Agnieszka Zimna ${ }^{1 *}$, Natalia Rozwadowska ${ }^{1}$, Monika Fraczek ${ }^{1}$, \\ Paulina Kucharzewska ${ }^{2}$, Marek Ruciński ${ }^{3}$, Tomasz Mietkiewski ${ }^{3}$, Tomasz Kolanowski ${ }^{1}$, \\ Agnieszka Malcher ${ }^{1}$, Maciej Kurpisz ${ }^{1}$ \\ ${ }^{1}$ Instytut Genetyki Człowieka, Polska Akademia Nauk, Poznań \\ ¿Zakład Biotechnologii Medycznej, Instytut Biochemii, Biofizyki i Biotechnologii, Uniwersytet Jagielloński, Kraków \\ ${ }^{3}$ Oddział Ortopedii, Szpital Wojewódzki, Poznań
}

*Obydwie autorki w równym stopniu przyczyniły się do wykonania badań.

Streszczenie

Wstęp: Nowoczesne terapie regeneracyjne stosowane w leczeniu serca po zawale skupiają się głównie na poprawie perfuzji w obszarze uszkodzonego miokardium. Efekt ten można osiągnąć m.in. poprzez wszczepienie w obszar blizny pozawałowej komórek macierzystych zmodyfikowanych czynnikami indukującymi powstawanie naczyń krwionośnych. Połączenie dwóch rodzajów terapii: komórkowej i genowej stanowi obiecującą metodę leczenia skutków zawału serca. Zapoczątkowanie tworzenia naczyń krwionośnych może się odbywać w sposób pośredni, poprzez uczestnictwo enzymu eNOS w stymulacji powstawania dużej ilości czynnika VEGF, będącego głównym induktorem angiogenezy. Dodatkowo produkt enzymu eNOS — tlenek azotu jest cząsteczką, która ma duże znaczenie dla fizjologii organizmu; przyczynia się m.in. do rozszerzania naczyń krwionośnych, stymuluje komórki śródbłonka, zapobiega agregacji płytek krwi i adhezji leukocytów w naczyniach.

Cel: Głównym celem pracy było sprawdzenie potencjału regeneracyjnego i właściwości proangiogennych zmodyfikowanych genetycznie komórek macierzystych mięśni szkieletowych, zarówno pierwotnej zawiesiny ludzkiej, jak i mysich komórek linii C2C12 za pomocą konstrukcji genowej zawierającej sekwencję kodującą dla genu eNOS.

Metody: Komórki macierzyste (ludzkie i mysie) były hodowane w standardowych warunkach in vitro. Następnie obydwa typy komórek zostały zmodyfikowane za pomocą elektroporacji i lipofekcji (ta ostatnia dla komórek mysich). Wydajność transfekcji sprawdzono za pomocą cytometrii przepływowej. Stężenie białka eNOS oznaczono testem immunoenzymatycznym ELISA. Podstawowe funkcje biologiczne zmodyfikowanych komórek zostały ocenione przy użyciu testu proliferacyjnego MTT oraz DAPI do analizy cyklu komórkowego. Wpływ stresu oksydacyjnego na przeżywalność komórek zbadano cytometrycznie, wykorzystując aneksynę V i jodek propidyny. Aby ocenić, czy ekspresja genów szlaku miogennego nie została zaburzona przez wniesioną modyfikację genetyczną, przeprowadzono reakcję PCR w czasie rzeczywistym. Funkcjonalność zastosowanej modyfikacji genetycznej sprawdzono za pomocą testu proliferacji komórek HUVEC z użyciem mediów zebranych znad poszczególnych populacji komórek po hodowli.

Wyniki: Elektroporacja okazała się wydajną metodą transfekcji pierwotnych komórek ludzkich. Otrzymano wysokie stężenie białka eNOS w przypadku obu badanych rodzajów komórek: mysich i ludzkich (> 2000 pg/ml). Funkcjonalność modyfikacji potwierdzono w teście tworzenia kapilar przez komórki HUVEC. Ludzkie mioblasty nie wykazały żadnych istotnych zmian w cyklu komórkowym, natomiast komórki mysie wykazały istotny statystycznie spadek we współczynniku proliferacji (na poziomie istotności p $<0,001$ ). W profilu ekspresji genów miogennych istotny statystycznie okazał się jednie spadek ekspresji miogeniny w przypadku mioblastów ludzkich $(p<0,05)$. Przeżywalność komórek modyfikowanych nie odbiegała znacząco od wyników uzyskanych w przypadku komórek 'natywnych'.

Wnioski: Wyniki badań wskazują na słuszność zastosowania modyfikacji genetycznej komórek macierzystych z perspektywicznym planem użycia genu eNOS w badaniach przedklinicznych na modelu mysim. Taka terapia może się okazać w przyszłości obiecującym sposobem regeneracji serca po zawale.

Słowa kluczowe: angiogeneza, mioblasty, komórki macierzyste, eNOS, medycyna regeneracyjna

Kardiol Pol 2013; 71, 10: 1048-1058

\section{Adres do korespondencji:}

dr n. med. Maciej Kurpisz, Instytut Genetyki Człowieka, Polska Akademia Nauk, ul. Strzeszyńska 32, 60-479 Poznań, tel: +48 616579 202/212,

faks: +48618233 235, e-mail: kurpimac@man.poznan.pl

Praca wpłynęła: 26.10.2012 r. Zaakceptowana do druku: 20.03.2013 r. 